\title{
Weathering and mineralogical evolution in a high Alpine soil chronosequence: A combined approach using SEM-EDX, cathodoluminescence and Nomarski DIC microscopy
}

\author{
Mavris, Christian ; Götze, Jens ; Plötze, Michael ; Egli, Markus
}

\begin{abstract}
Physical and chemical weathering of primary minerals of granitic till in the proglacial area of Morteratsch (Switzerland) was investigated using cathodoluminescence (CL), Nomarski differential interference contrast (DIC) microscopy and scanning electron microscope (SEM-EDX). The investigated time-span ranges from 0 to 140 years of sediment exposure. For the very early stage of weathering or soil formation only little information is available. The main aim of our investigation was consequently to see whether weathering of primary minerals can be detected in such a short time-span using for the first time for soils well-established methods as CL and Nomarski DIC microscopy in geo- and material science such. For that purpose, the fine earth fraction $(<2 \mathrm{~mm})$ of topsoil samples was investigated. Some physical weathering had taken place within 140 years. The delamination of biotite seems to increase with time. SEM and CL analyses also demonstrate early weathering of quartz by evidencing edge pits and structural bonds - such as Si-O-Si in quartz - that start to break and to transform into free radicals. K-feldspar and plagioclase contain Fe. When using Fe3+ as reference point (680-700 nm) to standardise the CL spectra, the Al-O -Al defects of K-feldspar exhibit a relative decrease with time; this was not the case for plagioclase. The CL measurements showed that the investigated apatite contained REE (rare earth elements) in the crystal structure. However, none of the other techniques (DIC, SEM-EDX) was helpful in detecting any specific weathering features for apatite. In the time span of 140 years, epidote weathering was evidenced using XRD in a previous investigation and here using DIC microscopy (morphologic changes). Several mineral changes could be traced within a very short weathering sequence using the applied techniques. These changes include physical (e.g. biotite), chemical or crystal structure (K-feldspar, biotite) features. Such an analytical combination is promising, therefore, for the detection of chemical, physical and mineralogical characteristics and changes in very young glacial sediments.
\end{abstract}

DOI: https://doi.org/10.1016/j.sedgeo.2012.04.008

Posted at the Zurich Open Repository and Archive, University of Zurich

ZORA URL: https://doi.org/10.5167/uzh-67083

Journal Article

Accepted Version

Originally published at:

Mavris, Christian; Götze, Jens; Plötze, Michael; Egli, Markus (2012). Weathering and mineralogical evolution in a high Alpine soil chronosequence: A combined approach using SEM-EDX, cathodoluminescence and Nomarski DIC microscopy. Sedimentary Geology, 280:108-118.

DOI: https://doi.org/10.1016/j.sedgeo.2012.04.008 


\section{Weathering and mineralogical evolution in a high Alpine soil}

2 chronosequence: a combined approach using SEM-EDX,

3 cathodoluminescence and Nomarski DIC microscopy

4

5 Christian Mavris ${ }^{1 *}$, Jens Götze ${ }^{2}$, Michael Plötze $^{3}$, Markus Egli $^{1}$

$6{ }^{1}$ Department of Geography, University of Zurich, Winterthurerstrasse 190, CH-8057 Zürich,

$7 \quad$ Switzerland

$8{ }^{2}$ TU Bergakademie Freiberg, Institute of Mineralogy, Brennhausgasse 14, D-09596 Freiberg,

9 Germany

$10{ }^{3}$ ETH Zurich, Institute for Geotechnical Engineering, Zurich, $\mathrm{CH}-8093$, Switzerland

*corresponding author:

tel. +41446355114

fax: +414463563848

christian.mavris@geo.uzh.ch

\section{Abstract}

19 Physical and chemical weathering of primary minerals of granitic till in the proglacial area of

20 Morteratsch (Switzerland) was investigated using cathodoluminescence (CL), Nomarski

21 differential interference contrast (DIC) microscopy and scanning electron microscope (SEM-

22 EDX). The investigated time-span ranges from 0 to $140 \mathrm{yr}$ of sediment exposure. For the

23 very early stage of weathering or soil formation only little information is available. The main

24 aim of our investigation was consequently to see whether weathering of primary minerals can

25 be detected in such a short time-span using for the first time for soils well-established

26 methods as CL and Nomarski DIC microscopy in geo- and material science such. For that 27 purpose, the fine earth fraction $(<2 \mathrm{~mm})$ of topsoil samples was investigated. Some physical 
weathering had taken place within 140 years. The delamination of biotite seems to increase with time. SEM and CL analyses also demonstrate early weathering of quartz by evidencing edge pits and structural bonds - such as Si-O-Si in quartz - that start to break and to transform into free radicals. K-feldspar and plagioclase contain $\mathrm{Fe}$. When using $\mathrm{Fe}^{3+}$ as reference point $(680-700 \mathrm{~nm})$ to standardise the $\mathrm{CL}$ spectra, the $\mathrm{Al}-\mathrm{O}-\mathrm{Al}$ defects of $\mathrm{K}$ feldspar exhibit a relative decrease with time; this was not the case for plagioclase. The CL measurements showed that the investigated apatite contained REE (rare earth elements) in the crystal structure. However, none of the other techniques (DIC, SEM-EDX) were helpful in detecting any specific weathering features for apatite. In the time span of 140 years, epidote weathering was evidenced using XRD in a previous investigation and here using DIC microscopy (morphologic changes). Several mineral changes could be traced within a very short weathering sequence using the applied techniques. These changes include physical (e.g. biotite), chemical or crystal structure (K-feldspar, biotite) features. Such an analytical combination is promising, therefore, for the detection of chemical, physical and mineralogical characteristics and changes in very young glacial sediments.

Keywords: cathodoluminescence; Nomarski DIC microscopy; SEM-EDX; weathering; soil formation; proglacial area; feldspar; plagioclase; quartz; apatite

\section{Introduction}

Due to global warming, glaciers retreat and new areas are exposed to weathering. Glaciers and discontinuous permafrost in these ecosystems react sensitively to atmospheric warming because the year-round temperature of their surrounding is not greatly below their melting point (Haeberli and Beniston, 1998). The abrasive action of active ice masses produces

53 sediments (i.e. moraines), which tend to weather as a function of their exposure time. In the 54 chemical sense, soil development is roughly synonymous with weathering. Elemental and mineralogical compositions of soils evolve due to complex feedbacks among geochemical 
56 and geomorphic processes within and at the boundaries of the soil layer. Geochemical 57 processes involve dissolution, leaching, precipitation and colloidal translocation (Yoo and 58 Mudd, 2008), whereas geomorphic processes include the conversion of parent material to 59 soil materials and the colluvial transport of the soil materials.

60 It is often assumed that weathering mechanisms in cold regions are slow due to the low 61 temperatures. The proglacial area is, however, a potential zone of a) high geochemical 62 reactivity due to the availability of freshly-ground reactive material (subglacially derived), b) 63 high water-to-rock ratios and contact times, c) high permeability, and d) a constant supply of 64 dilute waters (meltwaters and rain/snowmelt) percolating through the deposits. All these 65 factors should favour chemical weathering. There is no agreement about the velocity of reaction in proglacial areas. Anderson et al. $(1997,2000)$ concluded from their measurements that silicate weathering reactions in proglacial areas may be important only after a vegetation cover is established. In contrast, Wadham et al. (2001), Egli et al. (2003) and Hosein et al. (2004) suggest that glacially derived material is subjected to intense chemical weathering, starting immediately after deposition in the proglacial zone and

71 subsequently continuing for thousands of years after glacier retreat. Hosein et al. (2004) and Föllmi et al. (2009a,b) measured high weathering rates in proglacial 73 areas in the Alps $\left(10^{-15}\right.$ to $10^{-13}$ mol biotite $\mathrm{m}^{-2} \mathrm{~s}^{-1}$ for a $140-270 \mathrm{yr}$-old exposed proglacial 74 area). Biotite weathering in young soils was generally much higher than in old soils. The 75 calculated weathering rates of biotite were several orders of magnitude higher than known 76 field weathering rates (e.g., Swoboda-Colberg and Drever, 1993; Murphy et al., 1998). This 77 seems to be related to the predominance of fine-grained particles $(<63 \mu \mathrm{m})$ in glacial 78 sediment that are mechanically disaggregated and preferentially leached.

79 In general, the availability of data about weathering rates and alteration of primary rock80 forming minerals in young and cold areas is scarce. The detection of changes is often limited 81 by the choice of techniques. The combination of transmitted-light cathodoluminescence (CL), 82 Nomarski DIC (Differential Interference Contrast) microscopy and scanning electron 83 microscopy (SEM-EDX) can give important insights into the chemical composition and crystal 
84 arrangement of minerals (i.e. point defects, cationic changes, etc.). Most materials have distinct luminescence properties that allow a rapid identification of phase distribution and transformation. Nomarski DIC microscopy is an optically-based technique first documented by Nomarski and Weill (1951) and Nomarski (1955). It allows the observation of micromorphological features in natural materials and/or metal alloys, and has been applied in reflected light microscopy in metallurgy and petrographic research (e.g. Pearce et al., 1987; Keevil and Walker, 1992). Despite a relatively straightforward preparation of the samples and the high amount of information that can be retrieved by the combination of $\mathrm{CL}$ and Nomarski DIC, their coupled application is rare (Götze and Siedel, 2004, 2007). Transmitted-light CL microscopy is a technique applied to building materials (Michalski et al., 2002; Götze and Siedel, 2007; Götze, 2009), archaeology (Lapuente et al., 2000; Götze and Siedel, 2004) and geosciences (e.g. Götze et al., 2000; 2004; Götze and Zimmerle, 2000; Richter et al., 2003). The aim of this study is to trace mineralogical and crystallographic changes in soils that have developed across a recently exposed granitic till. For that purpose, the proglacial area of the Morteratsch glacier was selected. The combination of preferential weathering patterns and elemental depletion (for the main structure modifier elements) for primary mineral phases were taken into account.

101 For this purpose, CL and Nomarski DIC microscopy - well-known analytical techniques in 102 material science but not applied so far for soil studies - analyses were performed in 103 combination with SEM-EDX. An additional aim was consequently to test the power and 104 suitability of these techniques for studying short-term and initial weathering processes in 105 young soils.

\section{Study area}

108 The proglacial area of Morteratsch is located in Upper Engadine, SE Switzerland (Fig. 1).

109 The valley runs in N-S direction and the current length of the exposed area is approx. $3 \mathrm{~km}$.

110 The glacier has been continuously retreating without re-advancements since the 1850s (end 111 of the Little Ice Age; Burga, 1999). The altitude of the investigated proglacial valley ranges 
112 from $1900 \mathrm{~m}$ asl to approx. $2150 \mathrm{~m}$ asl, with no abrupt stacks and slopes along its main axis.

113 Geologically, the glacial till consists of granitic material. The morainic material was produced

114 through glacial transport within a small area of relatively homogeneous parent material 115 (Mavris et al. 2010, 2011). The proglacial area of Morteratsch is set in the Lower 116 Austroalpine Bernina Nappe, which is mainly composed of plutonic rocks, such as 117 granodiorites, diorites, syenites and alkaligranites. Rarerly accessory rocks such as

118 dolomites, gabbros and serpentines are also reported (Büchi, 1994). In the investigated area, 119 these rock types were not observed (Mavris et al. 2010, 2011). The rock units underwent 120 greenschist facies metamorphism during the High Alpine orogenesis (Oligocene-Eocene; 121 Trommsdorff and Dietrich, 1999). This event caused the saussuritisation of primary rock122 forming plagioclases into albite, epidote and calcite (D'Amico et al., 1998).

123 The vegetation cover of the Morteratsch proglacial area has been studied by Burga (1999).

124 The first flowering plants colonising the young deglaciated surfaces are scattered individuals 125 of Epilobium fleischeri and Linaria alpina that appear after about 7 years. First plants of the 126 community Oxyrietum digynae appear after c. 12 years and disappear after c. 27 years. The 127 establishment of Larici-Pinetum cembrae forests takes place after about 77 years on sites 128 where the soil is more intensely weathered (Burga, 1999). The soils are weakly developed 129 and are mostly Lithic Leptosols (IUSS Working Group WRB, 2006; Table 1). Present climatic 130 conditions for the Morteratsch site are $0.5^{\circ} \mathrm{C}$ mean annual temperature and $1000-1300 \mathrm{~mm}$ 131 mean annual precipitation.

\section{$134 \quad$ Material and methods}

\section{Soil sampling and preparation}

137 Soil samples were collected from 10 soil pits distributed over the whole proglacial area (Fig.

138 1). This procedure resulted in the collection of a soil chronosequence of surfaces ranging 139 from 0 (starting from the glacier front or unweathered parent material) to 140 years old. Soil 
140 profiles were excavated down to the $\mathrm{C}$ horizon (Table 1). For each horizon, 1-2 $\mathrm{kg}$ of 141 material was collected. The parent material $(t=0 \mathrm{yr})$ is the unweathered glacial sediment 142 that can be found either at the glacier front or below the soils ( $\mathrm{C}$ horizon). The unweathered 143 parent material used for the optical investigations was collected at the bottom of the 144 excavated profiles or glacial front ( $n=7 \mathrm{C}$ horizon samples were considered). The soil and

145 parent material samples were oven-dried and sieved to $2 \mathrm{~mm}$ (Department of Geography, 146 University of Zurich, Switzerland). An aliquot of the fine earth sample $(<2 \mathrm{~mm})$ was washed 147 with de-ionised water and, when present, the suspended organic fraction $\left(<1 \mathrm{~g} / \mathrm{cm}^{3}\right)$ was 148 removed by floating. These samples were used for the preparation of thin sections. Fine 149 earth samples (material with a diameter $<2 \mathrm{~mm}$ ) were dispersed with an ultrasonic 150 disperser, then embedded in polyester resin and cut to a thickness of c. $30 \mu \mathrm{m}$ in order to 151 ensure a good transparency of the sample. Thin sections were then polished and carbon 152 coated. The grain size of the investigated minerals was in the range of 10 to $800 \mu \mathrm{m}$.

153 In total, > 20 grains were analysed using the Nomarski DIC microscopy or SEM-EDX.

156 The fine-earth fraction of $n=4$ topsoil samples and $n=1$ parent material were analysed using scanning electron microscopy (SEM) and energy-dispersive spectroscopy (EDS). The

158 analysis was performed using a Dual Beam Quanta 200 3D FEI coupled with EDX, with Dual 159 BSD detector and W emitter operating at an accelerating voltage of $20 \mathrm{kV}$. The EDS detector 160 is equipped with an ultra-thin window allowing detection of mineral elements and carbon. 161 EDS provided the elemental composition of the solid phases and helped to identify them 162 (point analyses and elemental maps). Investigations were performed on both thin sections 163 (carbon coated) and loose granular samples (uncoated) at the Institute for Building Materials 164 (ETH Zurich, Switzerland). Cathodoluminescence

167 Luminescence is a common phenomenon in inorganic and organic compounds, resulting 
168 from an emission transition of anions, molecules or a crystal from an excited electronic state

169 to a ground or other state having less energy (Götze, 2009). In the present study, $\mathrm{n}=4$

170 topsoils and $n=1$ parent material were investigated. CL measurements were carried out at

171 the Institute of Mineralogyof the TU Bergakademie Freiberg (Germany) using a hot cathode

172 CL microscope HC1-LM (Neuser et al., 1995). The system was operated at $14 \mathrm{kV}$

173 accelerating voltage and a current density of about $10 \mu \mathrm{A} / \mathrm{mm}^{2}$. Luminescence images were

174 taken on-line during CL operations using a Peltier-cooled digital video camera (KAPPA 961-

$1751138 \mathrm{CF} 20 \mathrm{DXC}$ ). CL spectra were recorded in the wavelength range 320 to $900 \mathrm{~nm}$ using

176 an Acton Research SP-2356 digital triple-grating spectrograph with a Princeton Pixi 256B

177 Spec 10 CCD detector that was attached to the CL microscope by a silica-glass fibre guide.

178 CL spectra were measured under standardised conditions (wavelength calibration by a Hg-

179 halogen lamp, spot width $30 \mu \mathrm{m}$, measuring time 1-5 s).

180 Spectral data evaluation was performed considering the relative intensity (counts/s) of the 181 luminescence emission from each sample. The CL spectra depend on the crystal orientation 182 (Barbarand and Pagel, 2001; Finch et al., 2003). Therefore, a comparison of the same 183 mineral type in different samples must be done carefully if the orientation is not the same. 184 Because we were analysing soil systems, a similar orientation of the investigated minerals (in 185 a time series) could not be achieved. A quantitative analysis of weathering in the considered 186 time-span was therefore not possible. To have, however, a semi-quantitative indication for K187 feldspar and plagioclase, peaks in the CL spectra were normalised to the Fe peak of the 188 minerals in the parent material and in the soil of interest.

\section{Nomarski DIC microscopy}

191 Nomarski DIC microscopy is a modern technique applied in material science to visualise 192 different phases and/or to image the surface relief of samples (Fig. 2). In the present study, $\mathrm{n}$

$193=4$ topsoils and $\mathrm{n}=1$ parent material were investigated. The polarisation objectives used 194 have a magnification/numerical aperture of $20 x / 0.50,40 x / 0.75$ and $50 x / 0.80$ with specific DIC 195 prisms for transmitted and reflected light studies (Götze, 2009). The microscope was coupled 
196 with a digital video camera. The investigations and observations were carried out at the

197 Institute of Mineralogy of the TU Bergakademie Freiberg (Germany).

Total element analysis

200 Element pools in the soil ( $\mathrm{Ca}, \mathrm{Mg}, \mathrm{Na}, \mathrm{K}, \mathrm{Si}, \mathrm{Fe}, \mathrm{Al}, \mathrm{Ti}$, and $\mathrm{Mn}$ ) were determined by a total 201 dissolution method for the parental material (average of $n=7 \mathrm{C}$ horizons) and the topsoils 202 having an age $>100 \mathrm{yr}(n=4$; Table 2). Oven-dried samples were dissolved using a mixture 203 of $\mathrm{HF}, \mathrm{HCl}, \mathrm{HNO}_{3}$, and $\mathrm{H}_{3} \mathrm{BO}_{3}$ (Hossner, 1996) in a microwave oven and at a pressure of c. 20425 bar in a closed system. Concentrations were determined by an AAanalyst 600 Perkin 205 Elmer Atomic Absorption Spectrometer (AAS) at the Department of Geography, University of 206 Zurich (Switzerland).

\section{Results}

209 The soil mineralogy of the Morteratsch proglacial area has a predominantly silicatic character 210 due to the granitoid parent rock (Mavris et al. 2010, 2011 and Table 2). In the parent material 211 the most abundant phases detected were quartz, K-feldspar and Na-rich plagioclase followed 212 by Fe-rich mica (biotite) and epidote. Apatite was also detected. Furthermore, accessory 213 phases such as pyrite, titanite and ilmenite were detected, but were not the object of this 214 study. Secondary phases due to weathering were almost undetectable. The total 215 concentration of elements remains stable with exposure time (Table 2). The variability is 216 predominantly due to some inhomogeneities of the glacial sediment.

217 The morphology of the minerals is characterised by smooth surfaces and sharp angles 218 typical for a low weathering degree and limited transport (see Figs. 3 and 4). The amount of 219 rounded grains is low, which is common for morainic material having a minimal chemical 220 leaching and limited transport.

223 SEM-EDX. Quartz grains of the parent material have sharp edges and conchoidal surfaces, 
224 typical for short glacial transport. Quartz from the 140 year old soil features a much more 225 uneven surface. The degree of roundness of the grains is higher, and at high magnifications 226 weak traces of chemical corrosion could be detected (Fig. 3). Elemental mapping of quartz 227 grains did not give any evidence of chemical changes following 140 years of weathering, 228 because, apart Si or O, all other elements were below the detection limit of EDS.

229 CL. The luminescence for the investigated quartz grains was homogeneously dark brown230 blue. Primary internal structures (e.g. growth zoning) were usually not observed in the quartz 231 crystals (Fig. 4). CL spectra of quartz indicated some structural changes. The observed 232 broad CL bands of quartz at $450 \mathrm{~nm}$ and $650 \mathrm{~nm}$ are typical for granitoid-pegmatitic quartz 233 (Richter et al., 2003). The first band represents a defect due to an oxygen vacancy (Stevens 234 Kalceff and Phillips, 1995). The second band is caused by 'nonbridging oxygen hole centres' 235 (NBOHC) (Götze et al., 2001; Fig. 2). A detailed observation of the quartz spectrum of the

236 fresh sediment revealed a small contribution at $620 \mathrm{~nm}$. This is attributed to Si-OH (silanol 237 groups) and becomes hindered by the broad 'NBOHC' band with time (Stevens Kalceff and 238 Phillips, 1995; Fig. 5). In addition, a pronounced band was detected at $710 \mathrm{~nm}$ for the quartz 239 of the parent material. This band most likely indicates a substitutional incorporation of $\mathrm{Fe}^{3+}$ 240 into the quartz lattice as observed in other silicate structures. This would be typical for the 241 alkali-metasomatic alteration (fenitisation) of the granite (Götze et al., 2001).

242 Nomarski DIC microscopy. This technique revealed a quite homogeneous morphology for 243 quartz. The rare fractures detected along the surface of the crystals showed that only - if 244 ever - a slight corrosive pre-exposure occurred. In the oldest soil, no clear weathering 245 features were observed.

247 Feldspar

248 SEM-EDX. K-feldspar and Na-plagioclase display similar chemical stability with respect to 249 weathering (Allen and Hajek, 1989). Morphologically, we were not able to clearly distinguish 250 the two phases using SEM. In the parent material, the grains appeared to be coarsely251 shaped, with sharp, regular cleavage edges, indicating short transport and mechanical 
252 abrasion. Across the grain surfaces, a diffuse roughness was observed in both parent

253 material and topsoil samples.

254 CL. The luminescence of K-feldspar showed a blue-violet colour (Fig. 4). Plagioclase showed 255 green luminescence, slightly fading as a function of time. The heterogeneous distribution of $256 \mathrm{CL}$ colours in feldspar minerals indicates weathering/alteration already in the initial rock 257 material. In the CL spectra two emission bands could be observed (Fig. 5). The band at C. $258460 \mathrm{~nm}$, whose intensity decreases with soil age, is related to Al-O-Al defects (e.g. Marfunin, 259 1979). The band at c. $680 \mathrm{~nm}$ is generated by Fe ${ }^{3+}$ impurities in Al lattice positions (Götze et 260 al., 1999).

261 Nomarski DIC microscopy. Na-plagioclase and K-feldspar exhibited similar features (Fig. 6). 262 Using parallel and crossed Nicols polarised light, the grains revealed surfaces having 263 distinctive, cross-cutting preferential cleavage fissures. Already in the glacial till, two sets of 264 weathering surfaces were distinguishable (Fig. 6). The first one (red arrow) is observed at the 265 outer part of the grain from where the fissures started to penetrate and propagate randomly 266 into the inner part of the mineral grain. The second one (black arrow) developed along 267 parallel sets of cleavage surfaces.

Biotite

270 SEM-EDX. Biotite occurs as layered aggregates with some typical perfect basal cleavages 271 (Fig. 7). In both the parent material and topsoil mechanical deformation and delamination of 272 the layers due to glacial abrasive activity was observed. Furthermore, Ti-containing minerals 273 (titanite?) and feldspar were detected among the mica layers (Fig. 8). SEM-EDX did not 274 evidence a development of secondary phases. In the surface layer and along fissures of the 275 biotite platelets, K appeared depleted compared to Fe due to leaching processes (Fig. 8).

276 CL. Biotite shows a very weak CL intensity because of the quenching by structural iron. 277 Therefore, neither images nor CL spectra were obtained.

278 Nomarski DIC microscopy. Within the weathering sequence, an increasing delamination of 279 biotite with time could be observed. Using the Nomarski technique and SEM, larger spaces 
between the mica layers were detectable in the older samples (Fig. 7). As a consequence of

281 the delamination process of mica, a much higher surface area became available for chemical

282 weathering. However, the presence of structurally weaker phases, i.e. newly-formed clay

283 minerals, could not be detected within the biotite platelets. This confirms physical - rather

284 than chemical - alteration of biotite.

285

Apatite (accessory phase)

SEM-EDX. In the glacial till, apatite was detected as sporadically occurring, euhedral crystals having a size of up to $30 \mu \mathrm{m}$. Despite a rather low resistance to weathering in soil profiles having low pH (Allen and Hajek, 1989; Taunton et al., 2000), it was still possible to find apatite crystallites in the oldest topsoil. The EDX measurements did not evidence any

291 significant chemical change in the considered time-span.

292 CL. Apatite was observed having a strong yellow luminescence emission but did not feature 293 any rim (or growing) structures in the crystal, reflecting a homogeneous composition of 294 apatite (Fig. 4). The CL emission spectra of apatite evidenced sharp emission lines of REE 295 together with a strong $\mathrm{Mn}^{2+}$ band at C. $560 \mathrm{~nm}$ (Mariano, 1988). A strong enrichment in $\mathrm{Ce}^{3+}$, $296 \mathrm{Nd}^{3+}, \mathrm{Sm}^{3+}$ and $\mathrm{Eu}^{2+}$ is typical for apatite originating from alkaline magmatic complexes 297 (Zhang et al., 1985; Fleischer and Altschuler, 1986; Mariano, 1988; Boudreau and Kruger, 298 1990; Kempe and Götze, 2002).

299 Nomarski DIC microscopy. The detected apatite particles were too small (i.e. $<30 \mu \mathrm{m}$ ) to be 300 properly analysed from a morphological point of view.

SEM-EDX. Epidote occurs mainly as elongated crystals having a size of $>50 \mu m$ (Fig. 9). In

304 the glacial till, no pre-exposure weathering traces were detected on the epidote crystals. EDX 305 revealed two varieties, a common Fe-rich and a sporadically-occurring REE-bearing epidote 306 (data not shown; see also Mavris et al., 2010). The occurrence of the REE-bearing phases 307 correlates with the dismantlement of pegmatite veins (cf. Büchi, 1994). Epidote did not show 
any distinct chemical or mechanical weathering alterations in the oldest topsoil.

309 CL: Epidote featured a very weak (dark green) luminescence glow. The needle structure of 310 the small crystals, coupled with the strong interfering luminescence of the hosting feldspar 311 did not allow spectral CL measurement of epidote.

312 Nomarski DIC microscopy. In contrast to SEM-EDX, a distinct epidote alteration was

313 traceable (Fig. 9). Epidote appeared to have a physically and chemically affected crystal 314 structure when compared to the associated (surrounding) phases. The differential 315 interference contrast evidenced this feature where epidote was associated to tectosilicate316 structured phases. Neither secondary clay minerals nor oxyhydroxides were observed on the 317 surface of epidote.

\section{Discussion}

320 The collapse of structure bonds is paramount for the transformation of primary tectosilicatic 321 structure into secondary phases (e.g. smectite; Aoudjit et al., 1995). Physical weathering 322 processes (such as freeze-thawing cycles) tend to weaken mineral crystal structures such as 323 large cation-bond tectosilicatic crystal lattices and thus facilitate a further step of elemental 324 leaching by circulating waters (e.g. Hall et al., 2002). The chemical and mineralogical 325 structure of mineral, such as the $\mathrm{Fe}(\mathrm{II})$ content, oxygen sharing (the resistance of a primary 326 mineral to weathering increases the degree of sharing of oxygen between adjacent $\mathrm{Si}$ 327 tetrahedra in the crystal lattice), lattice distortion etc. strongly determine weathering stability 328 (Curtis, 1976).

329 In the investigated till, it appears that structural bonds - such as Si-O-Si in quartz - start to 330 break and to transform into free radicals at very early stages of weathering (Figs 3 and 5). 331 This process was also shown in controlled dissolution experiments using quartz (Bennett et 332 al., 1988). The surface of quartz in aqueous solutions consists entirely of species derived 333 from the hydrolysis and hydroxylation of broken $=\mathrm{Si}-\mathrm{O}-\mathrm{Si}=$ and the subsequent protonation 334 and deprotonation of these sites (Furrer and Stumm, 1986; Brady and Walther, 1990). CL 335 spectroscopy was a helpful tool to detect such nano-scale features (Fig. 5). The increase of 
336 both oxygen vacancy and 'NBOHC' bands is the direct consequence of the bond 337 disintegration and a subsequent leaching of $\mathrm{Si}$ (or other accessory impurities present, if any).

338 In both, the parent material and the oldest soil of the glacier forefield, the presence of apatite 339 could be verified. Apatite, the main source of inorganic P in the Morteratsch proglacial area, 340 neither displays significant chemical and structural changes nor specific dissolution patterns, 341 even after 140 years of weathering. This is in contrast to the findings of Föllmi et al. (2009b).

342 Their observations of the progressive change in surface morphology of whole apatite grains, 343 the systematic shift in the composition of $P$ phases from detrital to iron-bound and organic $P$ 344 and estimations of the weathering rate of detrital $P$ in the moraine samples indicated that 345 apatite is biogeochemically actively weathered in the proglacial areas of the Rhône and 346 Oberaar glaciers. That we do not observe such a trend in the proglacier area of Morteratsch 347 might be due to a different chemical composition of the apatite or the low number of 348 observations. The CL measurements seem to indicate a weathering of REE in the 349 investigated apatite; however, due to technical constraints, a definitive conclusion is not 350 possible.

351 The amount of epidote decreased as a function of time (see Mavris et al., 2010). Apparently, 352 the sorosilicate structure of epidote undergoes a leaching of major cations (predominantly $353 \mathrm{Ca}^{2+}$ ), thus featuring a chemically-changed crystal lattice (Fig. 9). However, an extended X354 ray absorption fine structure (EXAFS) spectroscopy study on Fe in the Damma glacier 355 forefield showed that the $\mathrm{Fe}$ fraction within epidote remained constant over the 356 chronosequence (of c. 150 years), indicating a rather low Fe weathering rate of epidote 357 (Kiczka-Cyriac, 2010).

358 Within the 140 years of weathering the Al-O-Al bonds of K-feldspar seemed to decrease 359 (Fig. 5) which might be due to a weakening of the crystal structure. Compared to Fe, less $\mathrm{Al}$ 360 structural bonds are present in the mineral structure. These structural changes were also 361 confirmed by the Nomarski DIC microscopy (Fig. 6). This reveals remarkable chemical 362 variations most often on the grain surface and at a lattice level. The standardised CL spectra 363 of plagioclase were overwhelmingly overlapping (Fig. 5F) and, consequently, no major 
364 changes could be observed. Finch et al. (2003) reported about a (structurally) ordered 365 plagioclase. The peak ratios after CL excitation/stimulation changed up to $34.3 \%$ with the 366 different crystallographic directions of the plagioclase. One way to detect the effective 367 change of specific bonds in a time series is the normalization (ratio) of the band of interest to 368 an 'inert' compound (such as $\mathrm{Fe}^{3+}$ in oxic environments). If this ratio varies between two 369 samples more than $34.3 \%$, a real crystallographic change is more likely. If we assume that 370 such a change as a function of orientation is also valid for the plagioclase in the Morteratsch 371 area then no changes can be measured after $140 \mathrm{yr}$ because the peak ratio changes remain 372 below this value. The Al-O-Al/Fe $(460 / 680 \mathrm{~nm})$ ratio is for 0 years (parent material) $=0.51$ 373 and for 140 years $=0.48$. The change in the $\mathrm{Al}-\mathrm{O}^{-}-\mathrm{Al} / \mathrm{Fe}$ ratio of $\mathrm{K}$-feldspar, however, 374 between 0 years (2.43) and 140 years (1.24) is much higher than one would expect from a 375 spectra-change of the same mineral with varying orientation (according to Finch et al., 2003). 376 Consequently, a part of the $\mathrm{Al}-\mathrm{O}^{-}-\mathrm{Al}$ decrease in the K-feldspar (Fig. 5E, F) must be 377 attributed to weathering (and not only to a change in orientation of the mineral).

378 Both chemical and physical transformations - namely, elemental depletion of $\mathrm{K}$ over $\mathrm{Fe}$, and 379 increased delamination over time - confirmed biotite weathering in the proglacial sediments 380 (Figs 7 and 8). As observed by other authors, biotite typically expands with time, delaminates 381 and contributes to an increase in porosity of the weathered rock (Meunier et al., 2007; Rossi 382 and Graham, 2010; Graham et al., 2010, Caner, 2011). The opening of fissures in mineral 383 grains and the increase in porosity finally give rise to accelerated alteration rates (chemical 384 weathering; Meunier et al., 2007). Fast weathering rates, not only of biotite, can usually be 385 observed at the beginning of soil formation when fresh and reactive surfaces are available 386 (Egli et al., 2003; Mavris et al. 2011). With time, these rates often decrease (Kump et al., 387 2000; Brantley and Mellott, 2000; Peters, 2009) due to the progressive occlusion of pores by 388 secondary minerals and a decreased chemical potential in the alteration product (Caner, 389 2011).

390 The combined CL/Nomarski DIC/ESEM observations of the Morteratsch sediments are 391 based on only a small number of observations. Consequently, our findings cannot be 
392 conclusive and, in particular, more CL measurements on individual minerals are required.

393 The total elemental concentration in the investigated topsoils reveals that the loss of

394 structure-modifying cations within the investigated time span of $140 \mathrm{y}$ is not yet high enough

395 to give rise to a chemical trend along the proglacial area (Table 2). However, on the much

396 smaller atomic and mineral structural scale weathering features can be detected using a

397 combination of CL, Nomarski and SEM-EDX techniques.

398

399

\section{Conclusions}

401 Active chemical and physical weathering in a high Alpine chronosequence of recently exposed, granitic sediments could be documented. We have the following main findings:

- Biotite shows distinct mechanical weathering due to delamination of layers within the 404 observed time-span of 140 years.

- Although the bulk chemistry of the soils did not change over time, K-feldspar and Na406 plagioclase showed some chemical transformations with respect to Al (K-feldspar) and $\mathrm{Mn}$ 407 (plagioclase). SEM-EDX analyses indicated a loss of $\mathrm{K}$ in biotite.

408 - Apatite seemed to be resistant to weathering.

409 - Epidote, however, shows clear weathering features (such as physical structure 410 disintegration) after 140 years.

411 The combined use of chemical, mineralogical and spectroscopic analyses proved to be a

412 useful approach in deciphering weathering patterns even at the atomic bond scale (crystal

413 structures). CL and Nomarski DIC have a great potential in detecting and analysing 414 chemical, physical and mineral structural changes due to weathering also in soils. Such an 415 approach should in future enable a qualitative and semi-quantitative estimation of lattice 416 position losses in primary and accessory minerals.

\section{Acknowledgements}

419 This research was supported by the Swiss National Foundation (SNF) project grant $\mathrm{n}$. 
200021-117568 and the SIMP fellowship 2009 (SIMP, Italian Society for Mineralogy and

Petrology, Italy). We would like to thank G. Peschke and F. Favilli for the help during fieldwork and in the laboratory. We are furthermore indebted to Dr. Carita Augustsson, Dr. Sergio Andò and the editorial staff of Sedimentary Geology for the fruitful comments to a previous version of the manuscript.

\section{References}

Aoudjit, H., Robert, M., Elsass, F., Curmi, P., 1995. Detailed study of smectite genesis in granite saprolites by analytical electron microscopy. Clay Minerals 30, 135-148.

Allen, B.L., Hajek, B.F., 1989. Mineral occurrence in soil environments. In: Dixon, J.B., Weed, S.B. (eds.) Minerals in Soil Environments. SSSA Book Series 1, 199-278.

Anderson, S.P., Drever, J.I., Humphrey, N.F., 1997. Chemical weathering in glacial environments. Geology 25, 399-402.

Anderson, S.P., Drever, J.I., Frost, C.D., Holden, P., 2000. Chemical weathering in the foreland of a retreating glacier. Geochimica et Cosmochimica Acta, 64, 1173-1189.

Barbarand, J., Pagel, M., 2001. Cathodoluminescence study of apatite crystals. American Mineralogist 86, 473-484.

Bennett, P. C., Siegeld, I., Melcerm, E., Bassett, J. P., 1988. The dissolution of quartz in dilute aqueous solutions of organic acids at $25^{\circ} \mathrm{C}$. Geochimica et Cosmochimica Acta 52, $1521-1530$.

Boudreau, A.E., Kruger, F.J., 1990. Variation in the composition of apatite through the Merensky cyclic unit in the Western Bushveld Complex. Economic Geology 85, 737-745.

Brady, P.V. and Walther, J.V., 1990. Quartz dissolution at low temperature. Chemical Geology 82, 253-264.

Brantley, S.L., Mellott, N., 2000. Surface area and porosity of primary silicate minerals. American Mineralogist, 85, 1767-1783.

nden, Schweiz). Schweizerische Mineralogische und Petrographische Mitteilungen 74, 359-371. 
Burga, C., 1999. Vegetation development on the glacier forefield Morteratsch (Switzerland). Applied Vegetation Science 2, 17-24.

Caner, L., 2011. Phyllosilicates des sols: de l'altération à la quantification. Habilitation, University of Poitiers, France.

Curtis, C. D., 1976. Stability of minerals in surface weathering reactions: A general thermochemical approach. Earth Surface Processes 1, 63-70.

D’Amico, C., Innocenti, F., Sassi, F. P., 1998. Magmatismo e Metamorfismo. Ed. UTET, Torino.

Egli, M., Mirabella, A., Fitze, P., 2003. Formation rates of smectites derived from two Holocene chronosequences in the Swiss Alps. Geoderma 117, 81-98.

Finch, A.A., Hole, D.E., Townsend, P.D., 2003. Orientation dependence of luminescence in plagioclase. Physics and Chemistry of Minerals 30, 373-381.

Fleischer, M., Altschuler, Z.S., 1986. The lanthanides and yttrium in minerals of the apatite group: an analysis of the available data r Mineralogie Monatshefte $10,467-480$.

Föllmi, K.B., Arn, K., Hosein, R., Adatte, T., Steinmann, P., 2009a. Biogeochemical weathering in sedimentary chronosequences of the Rhône and Oberaar Glaciers (Swiss Alps): rates and mechanisms of biotite weathering. Geoderma 151, 270-281.

Föllmi, K.B., Hosein, R., Arn, K., Steinmann, P., 2009b. Weathering and the mobility of phosphorus in the catchments and forefields of the Rhône and Oberaar glaciers, central Switzerland: Implications for the global phosphorus cycle on glacial-interglacial timescales. Geochimica et Cosmochimica Acta 73, 2252-2282.

Furrer, G., Stumm, W., 1986. The coordination chemistry of weathering: I. Dissolution kinetics of $\delta-\mathrm{Al}_{2} \mathrm{O}_{3}$, and BeO. Geochimica et Cosmochimica Acta 50, 1847- 1860.

Götze, J., Habermann, D., Neuser, R. D., Richter, D. K., 1999. High-resolution spectrometric analysis of rare earth elements-activated cathodoluminescence in feldspar minerals. Chemical Geology 153, 81-91.

Götze, J., Krbetschek, M.R., Habermann D., Wolf, D., 2000. High-resolution 
cathodoluminescence studies of feldspar minerals. In: Pagel, M., Barbin, V., Blanc P., 270.

Götze, J., Zimmerle, W., 2000. Quartz and silica as guide to provenance in sediments and sedimentary rocks. Contributions to Sedimentary Geology 12, 1-91.

Götze, J., Plötze, M., Habermann, D., 2001. Origin, spectral characteristics and practical applications of the cathodoluminescence $(C L)$ of quartz - a review. Mineralogy and Petrology 71, 225-250.

Götze, J., Plötze, M., Graupner, T., Hallbauer, D. K., Bray, C. J., 2004. Trace element incorporation into quartz: A combined study by ICP-MS, electron spin resonance, cathodoluminescence, capillary ion analysis, and gas chromatography. Geochimica et Cosmochimica Acta 68, 3741- 3759.

Götze J, Siedel H., 2004. Microscopic scale characterization of ancient building sandstones from Saxony (Germany). Material Characterization 53, 209-222.

Götze J, Siedel H., 2007. A complex investigation of building sandstones from Saxony (Germany). Material Characterization 58, 1082-1094.

Götze, J., 2009. Application of Nomarski DIC and cathodoluminescence (CL) microscopy to building material. Material Characterization 60, 594-602.

494 Graham, R.C., Rossi, A.M., Hubbert, K.R., 2010. Rock to regolith conversion: Producing hospitable substrates for terrestrial ecosystems. GSA Today 20, 4-9.

Haeberli, W., Beniston, M., 1998. Climate change and its impacts on glaciers and permafrost 497 in the Alps. Ambio, 27, 258-265.

498 Hall, K., Thorn, C.E., Matsuoka, N., Prick, A., 2002. Weathering in cold regions: some thoughts and perspectives. Progress in Physical Geography 26, 577-603.

500 Hosein, R., Arn, K., Steinmann, P., Adatte, T., Föllmi, K.B., 2004. Carbonate and silicate 501 weathering in two presently glaciated, crystalline catchments in the Swiss Alps. 502 Geochimica et Cosmochimica Acta 68, 1021-1033.

503 Hossner, C.R., 1996. Dissolution for total elemental analysis. In: Sparks, D.L. (Ed.), Methods 
of Soil Analysis, Part 3, Chemical Methods. Soil Science Society of America Inc. and American Society of Agronomy Inc., Madison, WI, 49-64.

IUSS Working Group WRB, 2006. World Reference Base for Soil Resources 2006, 2nd edition, World Soil Resources Reports No. 103, FAO (Food and Agriculture Organisation of the United Nations), Rome.

Keevil, C.W., Walker J., 1992. Nomarski DIC microscopy and image analysis of biofilms. Binary Computational Microbiology 4, 93-95.

Kempe, U., Götze, J., 2002. Cathodoluminescence (CL) behaviour and crystal chemistry of apatite from rare-metal deposits. Mineralogical Magazine 66, 151-172.

Kiczka-Cyriac, M., 2010. Iron isotope fractionation mechanisms of silicate weathering and iron cycling by plants. Ph.D. thesis, ETH Zurich.

515 Kump, L.R., Brantley, S.L., Arthur, M.A. 2000. Chemical weathering, atmospheric $\mathrm{CO}_{2}$, and climate. Annual Review Earth \& Planetary Sciences, 28, 611-617.

Lapuente, M.P., Turi, B., Blanc, P., 2000. Marbles from Roman Hispania: stable isotope and cathodoluminescence characterization. Applied Geochemistry 15, 1469-93.

Marfunin, A.S., 1979. Spectroscopy, luminescence and radiation centers in minerals. Springer-Verlag, Berlin.

Mariano, A.N., 1988. Some further geological applications of cathodoluminescence. In: Marshall, D.J. (ed.), Cathodoluminescence of Geological Materials. Unwin Hyman, Boston, USA, 94-123.

524 Mavris, C., Egli, M., Plötze, M., Blum, J.D., Mirabella, A., Giaccai, D., Haeberli, W., 2010. 525 Initial stages of weathering and soil formation in the Morteratsch proglacial area (Upper 526 Engadine, Switzerland). Geoderma 155, 359-371.

527 Mavris, C., Plötze, M., Mirabella, A., Giaccai, D., Valboa, G., Egli, M., 2011. Clay mineral 528 evolution along a soil chronosequence in an Alpine proglacial area. Geoderma 165, 106$529 \quad 117$.

530 Meunier, A., Sardini, P., Robinet, J.C., Prêt, D. 2007. The Petrography of weathering 531 processes. Facts and outlooks. Clay Minerals 42, 415-435. 
532 Michalski, S.T., Götze, J., Siedel, H., Magnus, M., Heimann, R.B., 2002. Investigations into provenance and properties of ancient building sandstones of the Zittau/Görlitz region (Upper Lusatia, Eastern Saxony, Germany). In: Siegesmund, S., Vollbrecht, A., Weiss, T., (Eds.), Natural stone, weathering phenomena, conservation strategies and case studies. Special Publications, vol. 205. London: Geological Society, pp. 281-295.

Murphy, S.F., Brantley, S.L., Blum, A.E., White, A.F., Dong, H., 1998. Chemical weathering in a tropical watershed, Luquillo Mountains, Puerto Rico: II. Rate and mechanism of biotite weathering. Geochimica et Cosmochimica Acta 62, 227-243.

Neuser, R.D., Bruhn, F., Gätze, F., Haberman, J., Richter, D.K., 1995. Kathodolumineszenz: Methodik und Anwendung. Zentralblatt für Geologie und Paläontologie Teil 1, 287-306.

Nomarski, G., Weill, A.R., 1951. Sur l'observation des figures de croissance des cristaux par les methods interférentielles à deux ondes. Société française de Minéralogie et de Cristallographie Bulletin 77, 840-868.

Nomarski, G., 1955. Microinterféromètre differentiell a ondes polarisées. Journal de Le Physique et Le Radium 16, 9-13.

Pearce, T.H., Russell, J.K., Wolfson, I., 1987. Laser-interference and Nomarski interference imaging of zoning profiles in plagioclase phenocrysts from the May 18, 1980, eruption of Mount St. Helens, Washington. American Mineralogist 72, 1131-1143.

Peters, C. A. 2009. Accessibilities of reactive minerals in consolidated sedimentary rock: An imaging study of three sandstones. Chemical Geology 265, 198-208.

Richter, D.K., Götte, T., Götze, J., Neuser R.D., 2003. Progress in application of cathodoluminescence $(\mathrm{CL})$ in sedimentary petrology. Mineralogy and Petrology 79, 127 166.

Rossi, A. M., Graham, R.C., 2010. Weathering and Porosity Formation in Subsoil Granitic Clasts, Bishop Creek Moraines, California. Soil Science Society of America Journal 74, 172-185.

Stevens Kalceff, M.A., Phillips, M.R., 1995. Cathodoluminescence microcharacterization of the defect structure of quartz. Physical Review 52, 3122-3135. 
560 Swoboda-Colberg, N.G., Drever, J.I., 1993. Mineral dissolution rates in plot-scale field and 561 laboratory experiments. Chemical Geology 105, 51-69.

562 Taunton, A.E., Welch, S.A., Banfield, J.F., 2000. Microbial control on phosphate and 563 lanthanide distributions during granite weathering and soil formation. Chemical Geology $564 \quad 169,371-382$.

565 Trommsdorff, V., Dietrich, V., 1999. Grundzüge der Erdwissenschaften. 6th edition, vdf$566 \quad$ Verlag, Zürich, Switzerland.

567 Wadham, J.L., Cooper, R.J., Tranter, M., Hodgkins, R., 2001. Enhancement of glacial solute 568 fluxes in the proglacial zone of a polythermal glacier. Journal of Glaciology 47, 378-386.

569 Yoo, K., Mudd, S.M., 2008. Toward process-based modelling of geochemical soil formation 570 across diverse landforms: A new mathematical framework. Geoderma 146, 248-260.

571 Zhang, S., Wang, L., Yang, W., 1985. Use of REE analysis in apatite to distinguish 572 petrological and mineralogical series of granitic rocks. Geochimica 1, 45-57. 


\section{Figure captions}

Fig. 1. Overview of the investigated area with the monitored sites in the proglacial area. The isochrones are according to Burga et al. (1999).

Fig. 2. Schematic sketch (modified after Götze, 2009) showing: a) simplified structure of quartz with some typical features detectable using cathodoluminescence (modified after Götze et al., 2001). b) Nomarski DIC microscopy. Optical diagram with the structure of the DIC microscope; bottom: the phase difference $(\Phi)$ is explained by geometric (step height ' $d$ ') and physical factors (difference in the material specific phase shift 'a' and 'b').

Fig. 3. SEM micrographs with a) quartz grain from the $140 \mathrm{yr}$ old topsoil and b) surface morphology showing an early chemical corrosion of quartz. The arrows point to distinct surface dissolution pits.

Fig. 4. Cathodoluminescence micrographs of apatite, quartz, plagioclase and alkali feldspar of the parent material $(0 \mathrm{yr})$ and $140 \mathrm{yr}$ old topsoil. Apatite: yellow luminescing crystals due to the activation of $\mathrm{Mn}^{2+}$; quartz: blue-brown $\mathrm{CL}$; plagioclase: green luminescing areas with strongly emitting $\mathrm{Mn}^{2+}$ peak; alkali feldspar. violet emitting grains, related to both $\mathrm{Al}-\mathrm{O}^{-}-\mathrm{Al}$ defects and $\mathrm{Fe}^{3+}$ in $\mathrm{Al}$-sites.

Fig. 5. Cathodoluminescence emission spectra of A) quartz, B) alkali feldspar, C) plagioclase and D) apatite. The bold line denotes the $140 \mathrm{yr}$ topsoil and the thin line the parent material. The spectra $\mathrm{E}$ (alkali feldspar) and F (plagioclase) are normalised to the Fe-spectrum of the parent material.

Fig. 6. Plagioclase from the parent material $(0 \mathrm{yr})$ and the $140 \mathrm{yr}$ old topsoil. In the parent material, two sets of weathering patterns are underlined: geologically inherited (along cleavage surfaces; red arrows), and pedogenic (mostly on the outer surface of the grains; black arrow). The image shows the grains in thin section in parallel and crossed Nicols transmitted (polarised) light. 
Fig. 7. (above) Delamination of biotite crystallites in the parent material $(t=0 \mathrm{yr})$ and in the oldest topsoil ( $\mathrm{t}=140 \mathrm{yr}$ ) observed using SEM; (below) biotite delamination as a function of the time documented using Nomarski DIC microscopy.

Fig. 8. Elemental mapping (SEM-EDX) of $\mathrm{K}$ and $\mathrm{Fe}$ in biotite of the parent material and the oldest soil.

Fig. 9. Micrographs of epidote from the parent material $(0 \mathrm{yr})$ and the oldest topsoil aged (140 yr). The image shows the grains in thin section in parallel and crossed Nicols transmitted (polarised) light. 


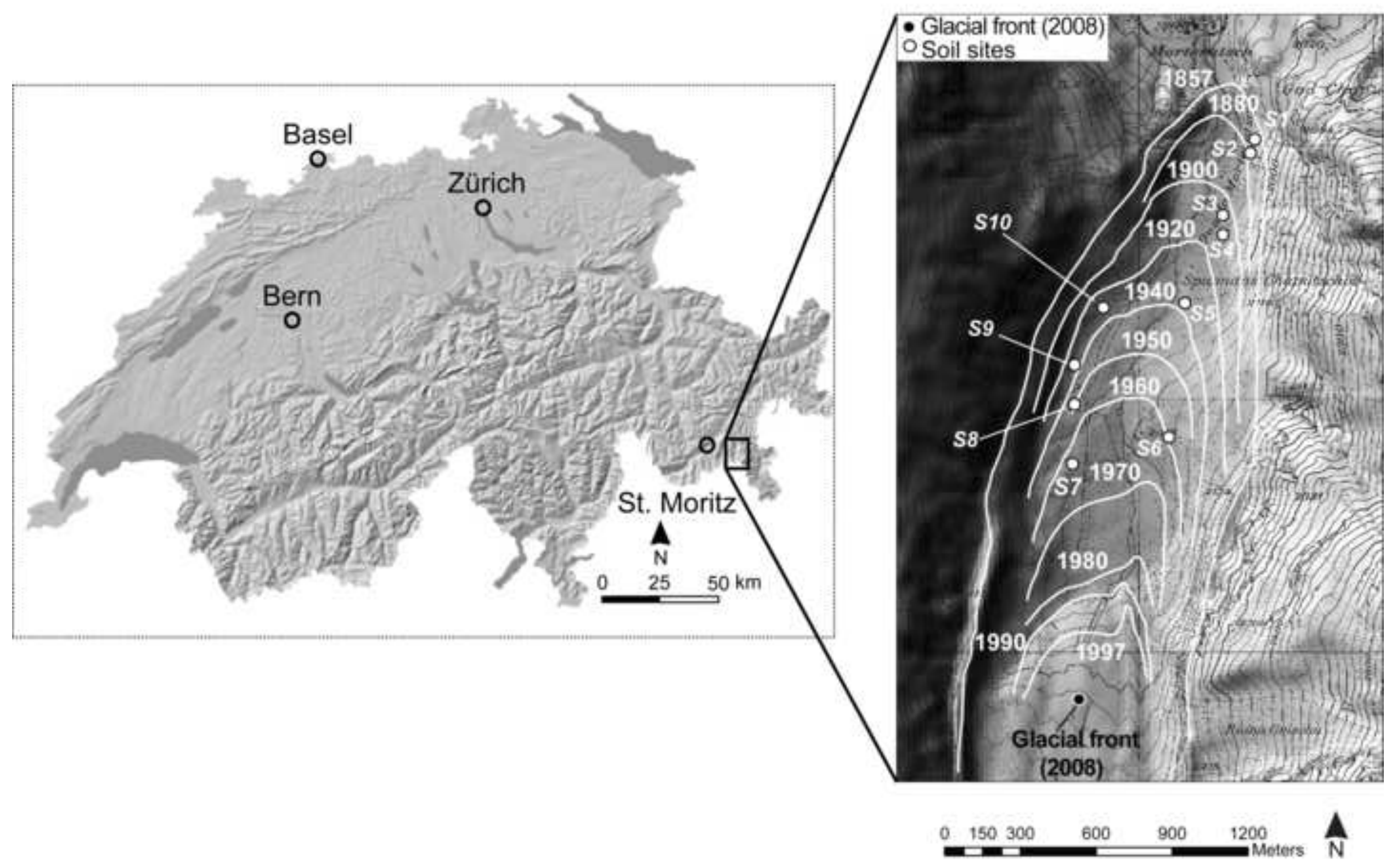


Click here to download high resolution image
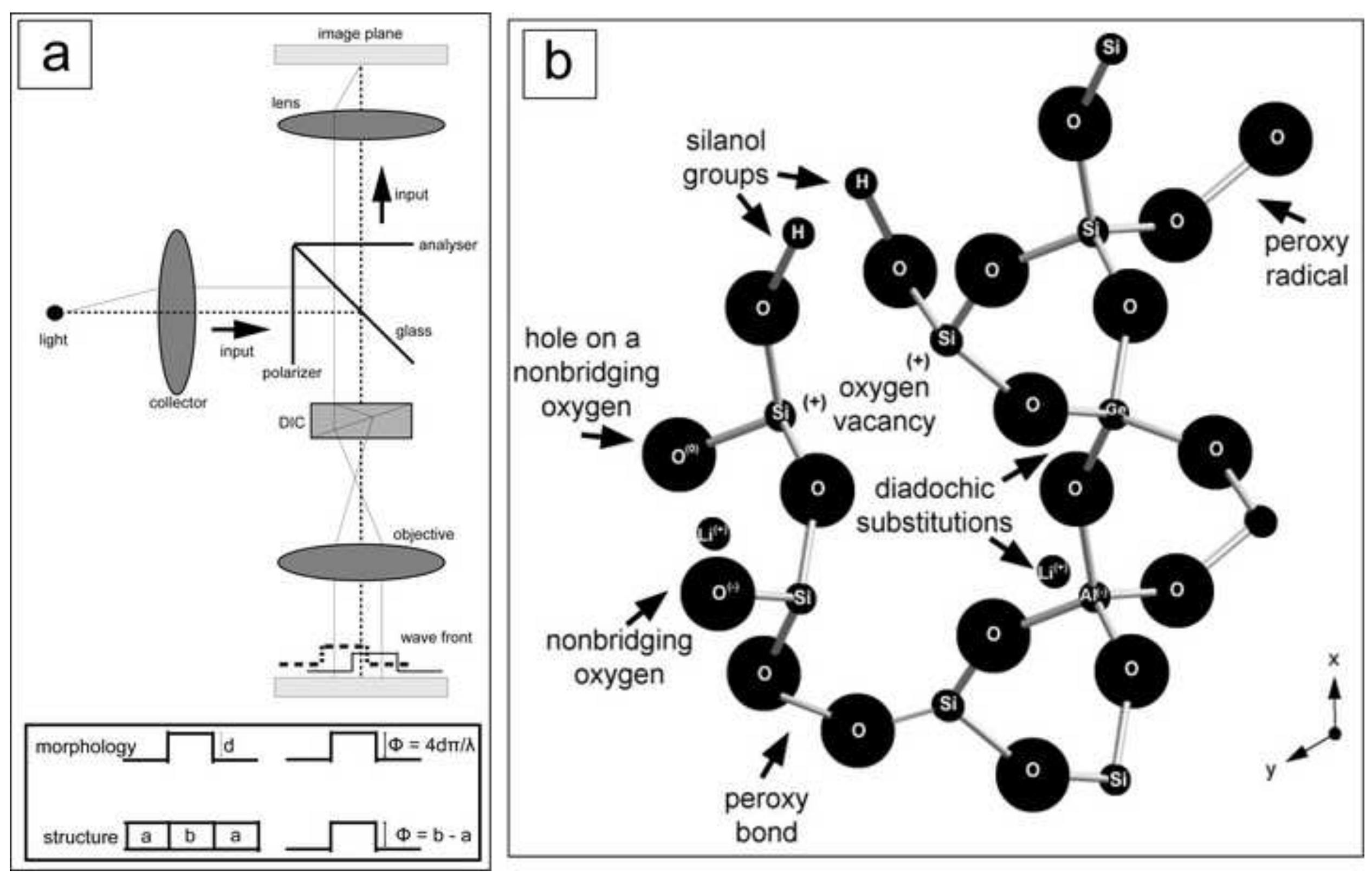


\section{Figure 3}

Click here to download high resolution image
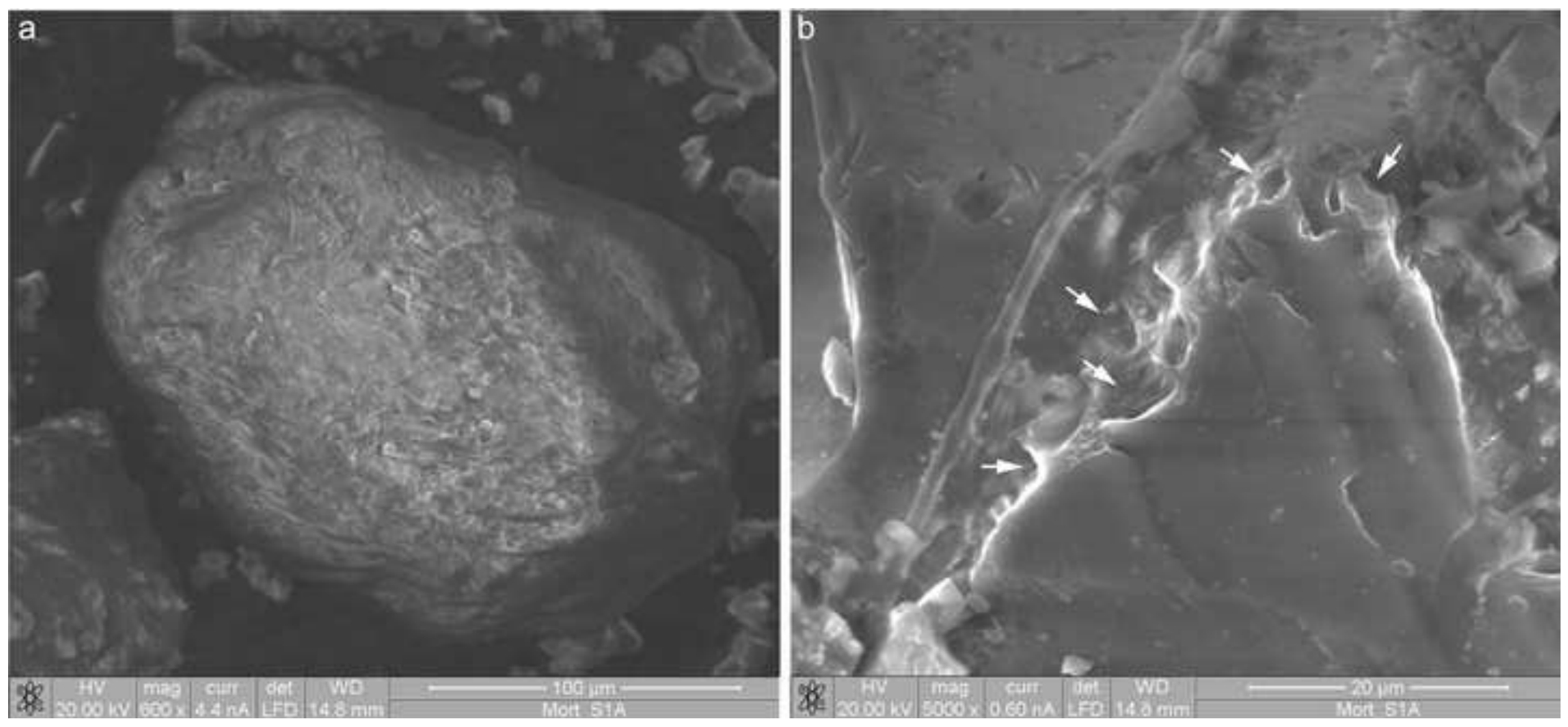

Click here to download high resolution image 
Click here to download high resolution image
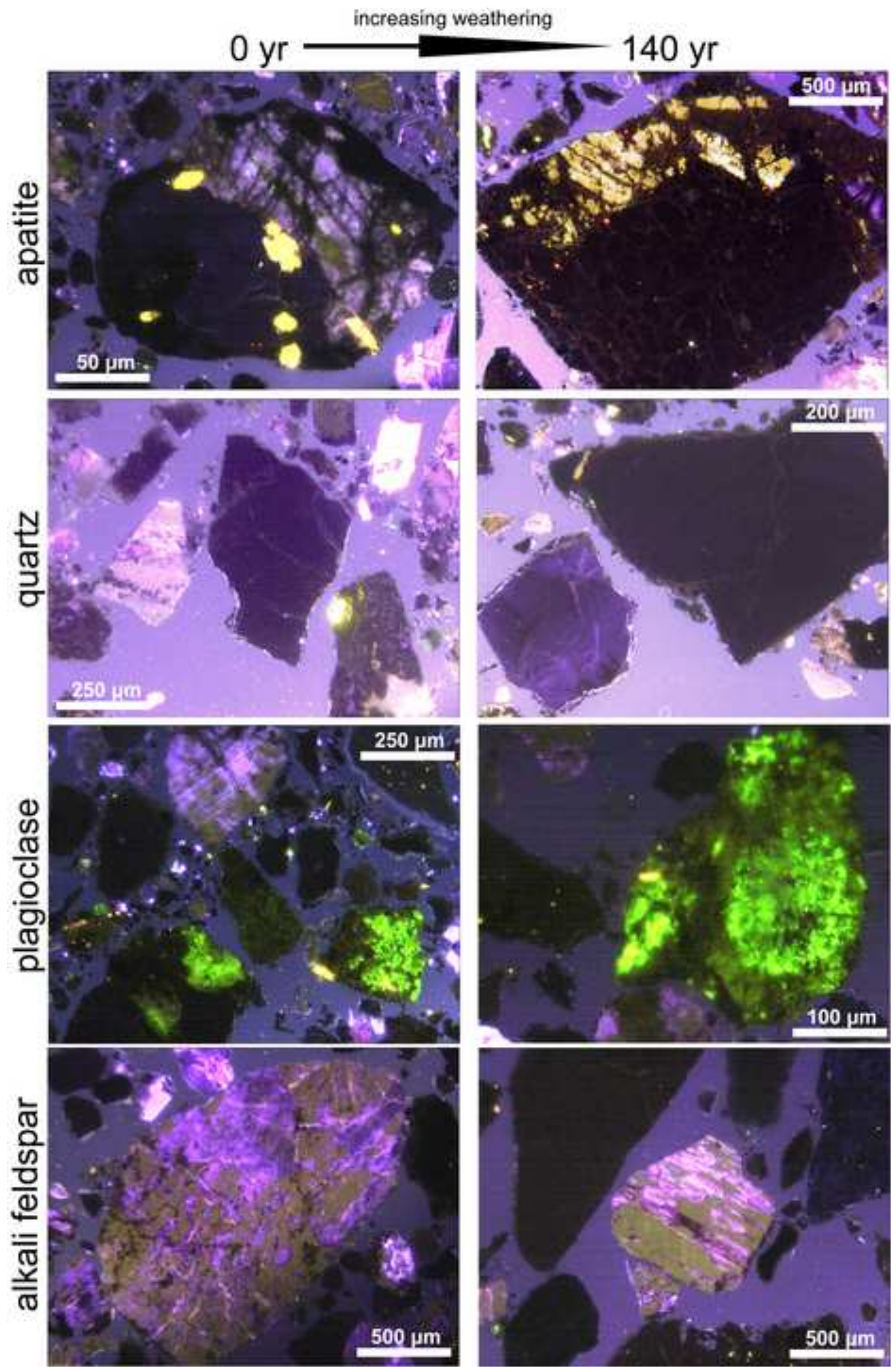


\section{Figure 5}

Click here to download high resolution image
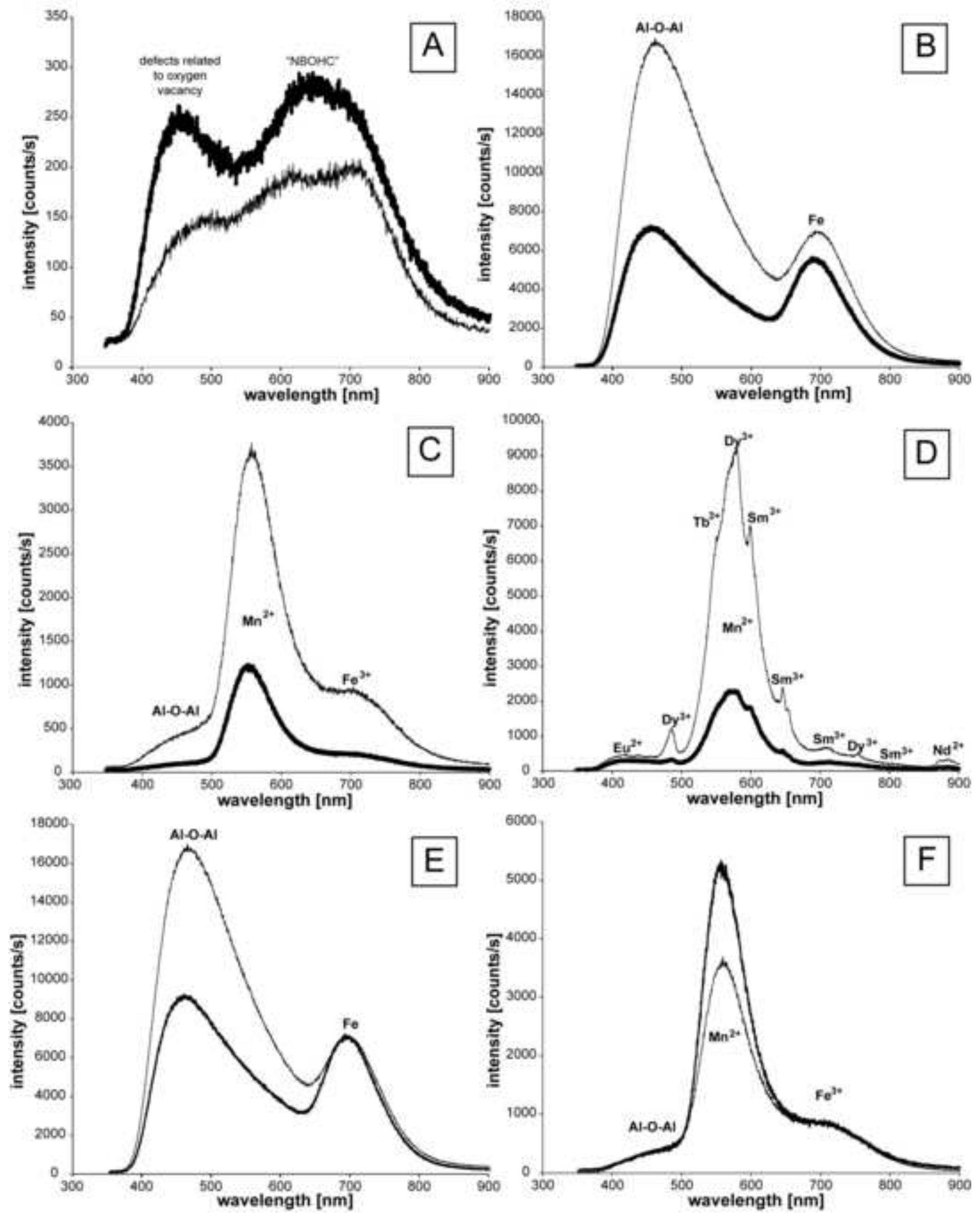

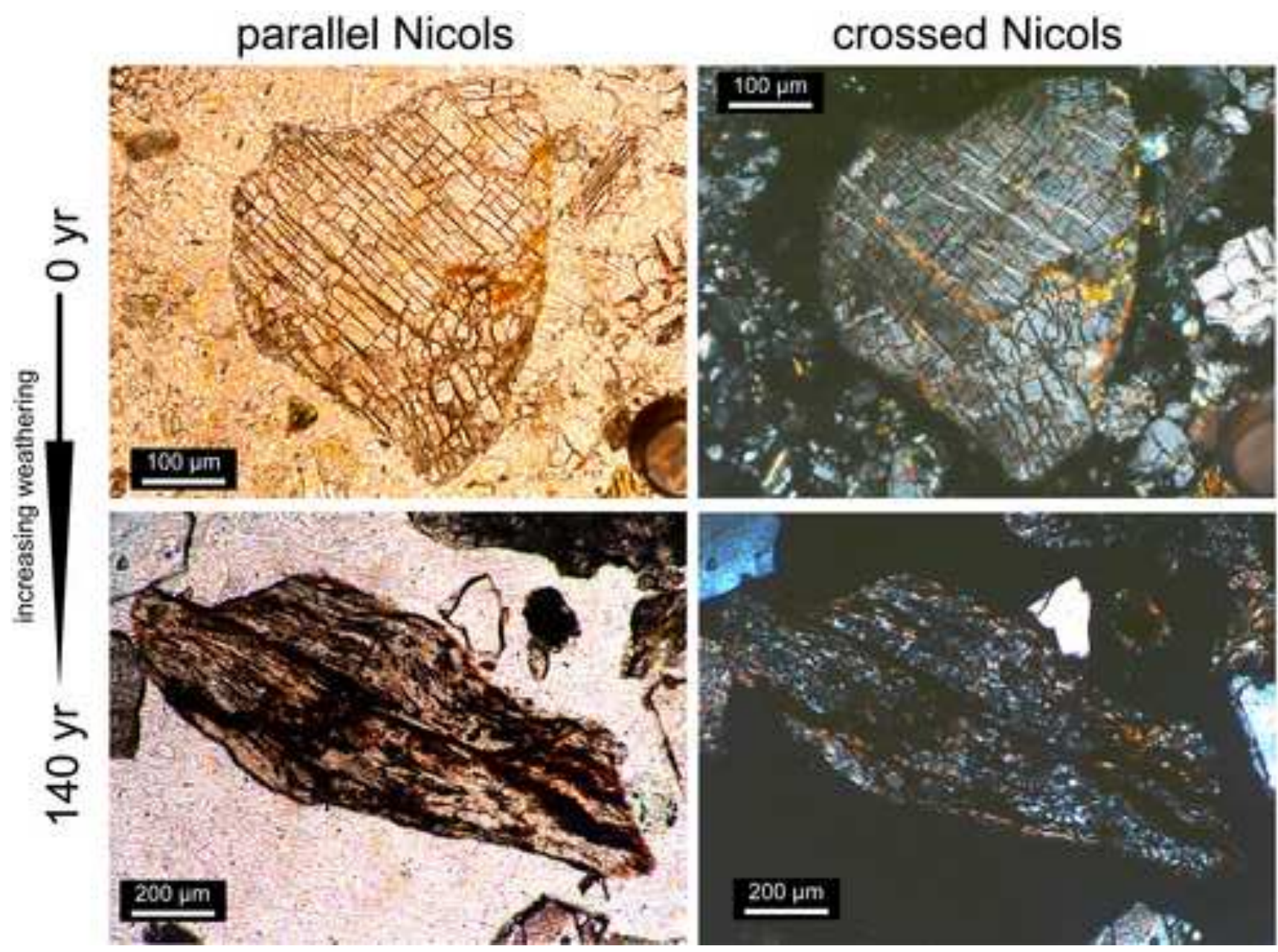

Nomarski DIC microscopy
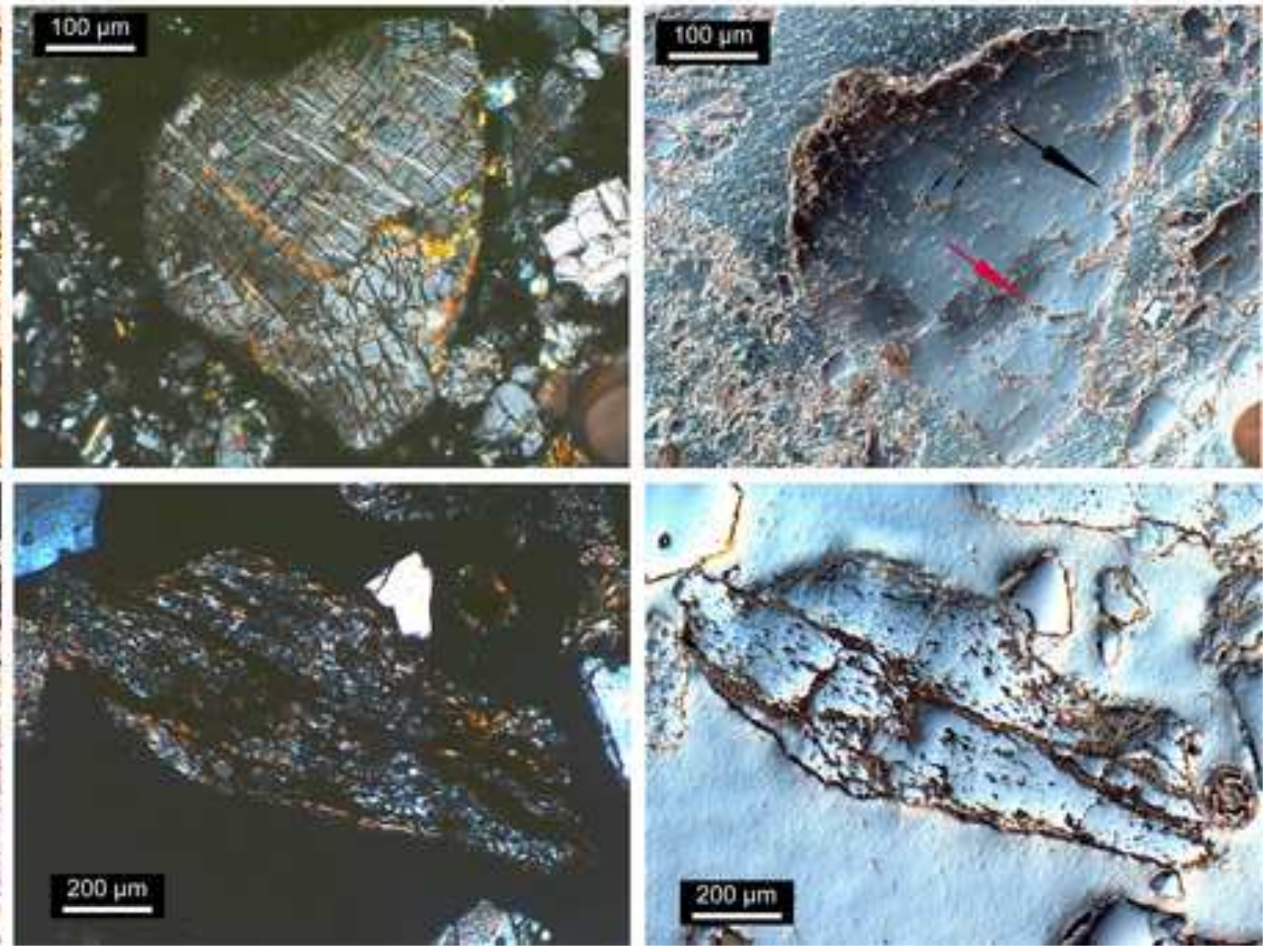
Click here to download high resolution image
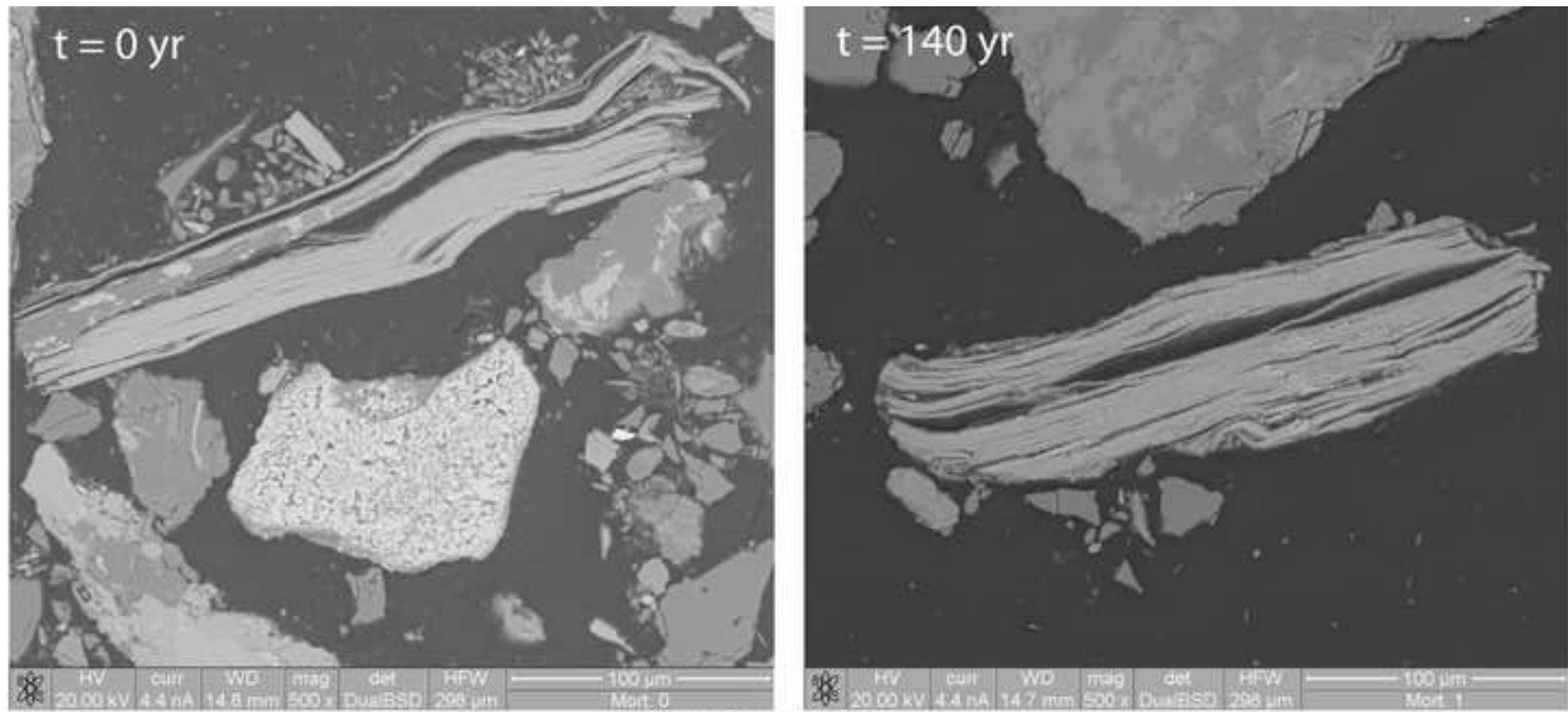

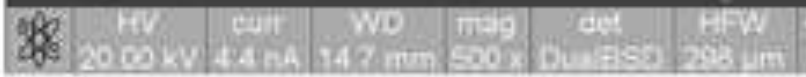
alogin increasing weathering

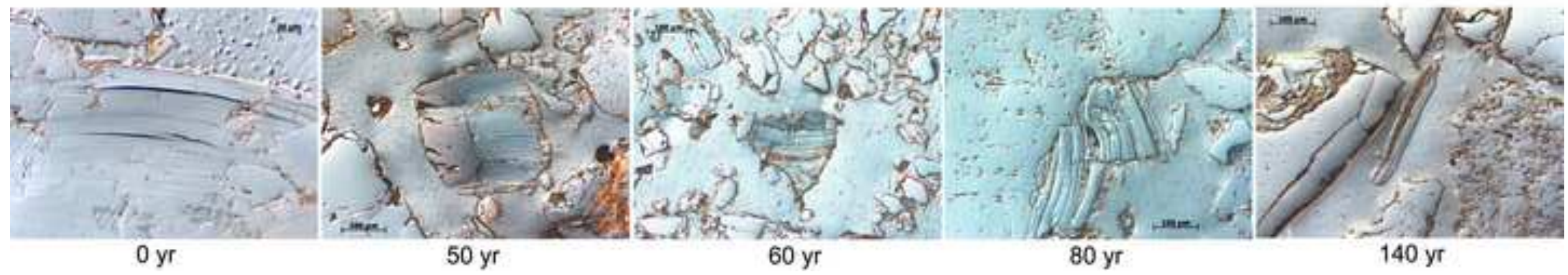


Click here to download high resolution image
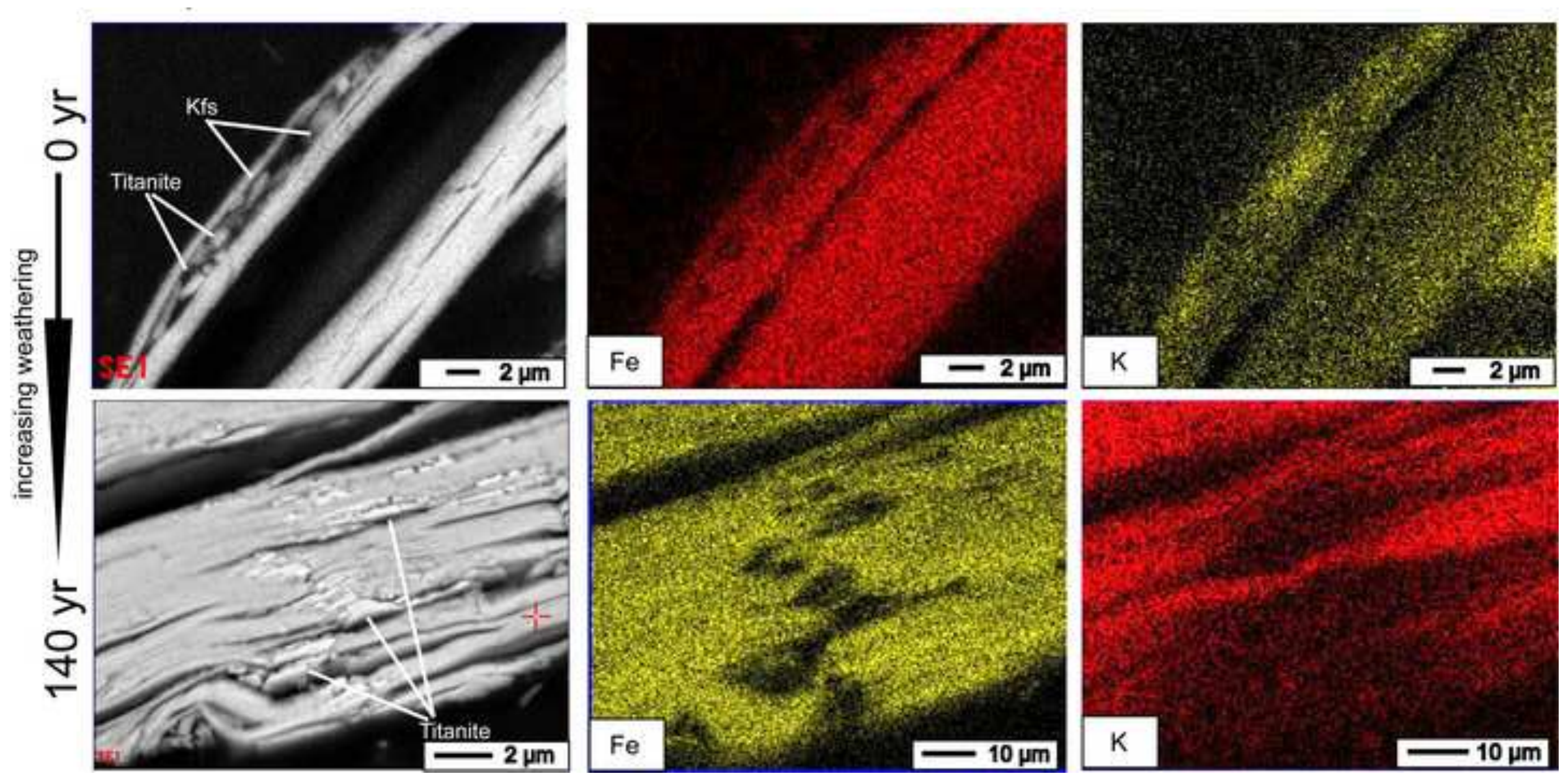


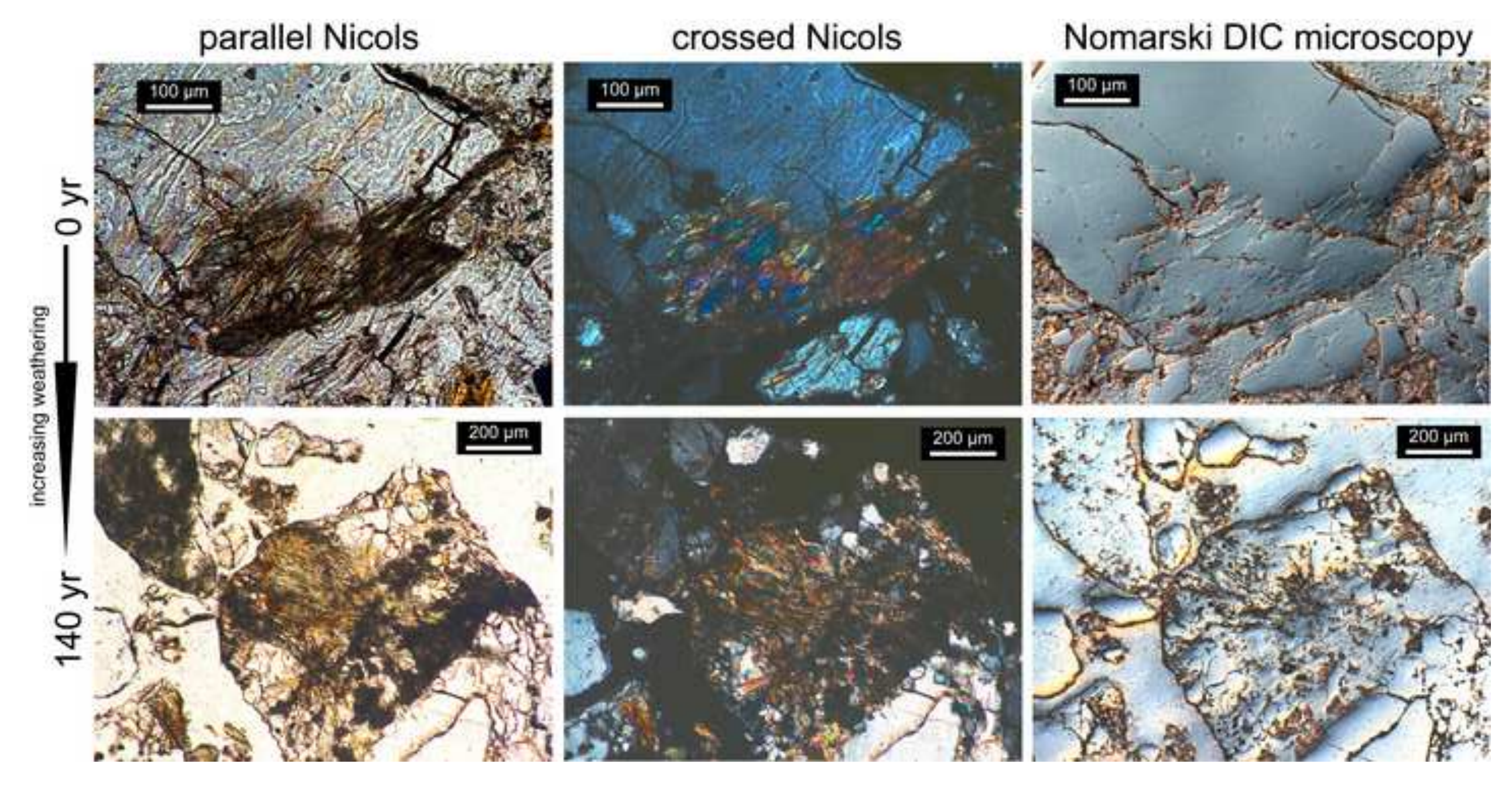


Table 1. Properties of the monitored soil sites. Grain sizes: sand (2000-63 $\mu \mathrm{m})$, silt $(63-2 \mu \mathrm{m})$ and clay $(<2 \mu \mathrm{m})$.

\begin{tabular}{|c|c|c|c|c|c|c|c|c|}
\hline Site/Soil & $\begin{array}{c}\text { Soil age } \\
(\mathrm{yr})\end{array}$ & Horizons & $\begin{array}{l}\text { Depth } \\
(\mathrm{cm})\end{array}$ & $\begin{array}{l}\text { Skeleton } \\
(\mathrm{wt} .-\%)\end{array}$ & $\begin{array}{l}\text { Sand } \\
(\mathrm{g} / \mathrm{kg})\end{array}$ & $\begin{array}{c}\text { Silt } \\
(\mathrm{g} / \mathrm{kg})\end{array}$ & $\begin{array}{l}\text { Clay } \\
(\mathrm{g} / \mathrm{kg})\end{array}$ & $\begin{array}{c}\mathrm{pH} \\
\left(\mathrm{CaCl}_{2}\right)\end{array}$ \\
\hline \multirow{4}{*}{$\begin{array}{l}\text { S1/Humi-Skeletic } \\
\text { Leptosol }\end{array}$} & \multirow[t]{4}{*}{138} & $\mathrm{O}$ & $0-6$ & 41 & n.m. & n.m. & n.m. & 4.60 \\
\hline & & $\mathrm{A}$ & $6-9$ & 50 & 777 & 184 & 39 & 4.80 \\
\hline & & $\mathrm{BC}$ & $9-14$ & 53 & 830 & 158 & 12 & 4.70 \\
\hline & & $\mathrm{C}$ & $14-30$ & 40 & 757 & 222 & 21 & 4.60 \\
\hline \multirow{2}{*}{$\begin{array}{c}\text { S2/Humi-Skeletic } \\
\text { Leptosol }\end{array}$} & \multirow[t]{2}{*}{128} & $\mathrm{~A}$ & $0-10$ & 64 & 754 & 204 & 42 & 4.85 \\
\hline & & $\mathrm{AC}$ & $10-40$ & 68 & 695 & 272 & 33 & 4.90 \\
\hline \multirow{2}{*}{$\begin{array}{c}\text { S3/Humi-Skeletic } \\
\text { Leptosol }\end{array}$} & \multirow[t]{2}{*}{108} & $\mathrm{~A}$ & $0-3$ & 54 & 667 & 265 & 68 & 5.10 \\
\hline & & $\mathrm{AC}$ & $3-15$ & 70 & 677 & 281 & 42 & 4.50 \\
\hline \multirow{3}{*}{$\begin{array}{c}\text { S4/Humi-Skeletic } \\
\text { Leptosol }\end{array}$} & \multirow[t]{3}{*}{98} & $\mathrm{~A}$ & $0-1$ & 55 & n.m. & n.m. & n.m. & 5.30 \\
\hline & & $\mathrm{AC}$ & $1-5$ & 51 & 939 & 61 & 15 & 5.20 \\
\hline & & $\mathrm{C}$ & $5-30$ & 70 & 931 & 57 & 12 & 5.20 \\
\hline \multirow{4}{*}{$\begin{array}{l}\text { S5/Humi-Skeletic } \\
\text { Leptosol }\end{array}$} & \multirow[t]{4}{*}{68} & A1 & $0-1$ & 7 & n.m. & n.m. & n.m. & 4.85 \\
\hline & & $\mathrm{A} 2$ & $1-4$ & 1 & 530 & 432 & 38 & 4.55 \\
\hline & & $\mathrm{C} 1$ & $4-9$ & 36 & 573 & 387 & 40 & 4.65 \\
\hline & & $\mathrm{C} 2$ & $9-20$ & 64 & 570 & 372 & 58 & 4.60 \\
\hline \multirow{2}{*}{$\begin{array}{c}\text { S6/Skeletic } \\
\text { Leptosol }\end{array}$} & \multirow[t]{2}{*}{48} & A & $0-2.5$ & 64 & n.m. & n.m. & n.m. & 4.80 \\
\hline & & $\mathrm{C}$ & $2.5-25$ & 68 & 852 & 129 & 19 & 5.00 \\
\hline \multirow{3}{*}{$\begin{array}{l}\text { S7/Skeletic } \\
\text { Leptosol }\end{array}$} & \multirow[t]{3}{*}{48} & $\mathrm{~A}$ & $0-4$ & 26 & n.m. & n.m. & n.m. & 6.10 \\
\hline & & $\mathrm{C} 1$ & $4-11$ & 37 & 823 & 146 & 31 & 5.20 \\
\hline & & $\mathrm{C} 2$ & $11-34$ & 67 & 747 & 211 & 42 & 5.10 \\
\hline \multirow{2}{*}{$\begin{array}{c}\text { S8/Skeletic } \\
\text { Leptosol }\end{array}$} & \multirow[t]{2}{*}{58} & $\mathrm{OA}$ & $0-12$ & 63 & n.m. & n.m. & n.m. & 4.60 \\
\hline & & $\mathrm{C}$ & $12-33$ & 48 & 712 & 220 & 68 & 4.40 \\
\hline \multirow{3}{*}{$\begin{array}{l}\text { S9/Humi-Skeletic } \\
\text { Leptosol }\end{array}$} & \multirow[t]{3}{*}{73} & $\mathrm{O}$ & $0-3$ & 44 & n.m. & n.m. & n.m. & 5.15 \\
\hline & & $\mathrm{AC}$ & $3-10$ & 65 & 785 & 175 & 40 & 4.40 \\
\hline & & $\mathrm{C}$ & $10-36$ & 58 & 832 & 133 & 35 & 4.65 \\
\hline \multirow{3}{*}{$\begin{array}{l}\text { S10/Humi-Skeletic } \\
\text { Leptosol }\end{array}$} & \multirow[t]{3}{*}{78} & A1 & $0-2$ & 49 & n.m. & n.m. & n.m. & 4.70 \\
\hline & & $\mathrm{A} 2$ & $2-10$ & 68 & 818 & 143 & 39 & 4.50 \\
\hline & & $\mathrm{AC}$ & $10-25$ & 84 & 733 & 219 & 48 & 4.80 \\
\hline
\end{tabular}

n.m. $=$ not measured 
Table 2. Total chemical analysis of the $>100 \mathrm{yr}$ topsoils $(\mathrm{n}=4)$ and the parent material $(\mathrm{n}=7)$ with standard deviation $(\mathrm{SD})$.

\begin{tabular}{|c|c|c|c|c|c|c|c|c|c|}
\hline & $\mathrm{Al}(\mathrm{g} / \mathrm{kg})$ & $\mathrm{Si}(\mathrm{g} / \mathrm{kg})$ & $\mathrm{Ti}(\mathrm{g} / \mathrm{kg})$ & $\mathrm{Ca}(\mathrm{g} / \mathrm{kg})$ & $\operatorname{Mg}(\mathrm{g} / \mathrm{kg})$ & $\mathrm{K}(\mathrm{g} / \mathrm{kg})$ & $\mathrm{Na}(\mathrm{g} / \mathrm{kg})$ & $\mathrm{Fe}(\mathrm{g} / \mathrm{kg})$ & $\operatorname{Mn}(g / k g)$ \\
\hline parent material & 76.8 & 310.2 & 8.00 & 17.2 & 9.53 & 28.7 & 26.8 & 22.5 & 0.58 \\
\hline $\mathrm{SD}$ & 6.5 & 27.4 & 2.38 & 6.4 & 3.20 & 4.1 & 3.87 & 6.9 & 0.16 \\
\hline $\begin{array}{c}\text { topsoils } \\
\text { (age }>100 \mathrm{yr})\end{array}$ & 65.0 & 330.4 & 5.90 & 27.3 & 7.32 & 28.1 & 25.3 & 29.1 & 0.62 \\
\hline
\end{tabular}

